Wyrok Sądu Metropolitalnego w Katowicach (c. Sobański) z 10.05.2001 r. z tytułu : 1) błędu co do przymiotu osoby, 2) podstępnego wprowadzenia w błąd, 3) niezdolności do podjęcia istotnych obowiązków małżeńskich (anoreksja)

Ius Matrimoniale 7 (13), 213-225

2002

Artykuł został zdigitalizowany i opracowany do udostępnienia w internecie przez Muzeum Historii Polski w ramach prac podejmowanych na rzecz zapewnienia otwartego, powszechnego i trwałego dostępu do polskiego dorobku naukowego i kulturalnego. Artykuł jest umieszczony w kolekcji cyfrowej bazhum.muzhp.pl, gromadzącej zawartość polskich czasopism humanistycznych i społecznych.

Tekst jest udostępniony do wykorzystania w ramach dozwolonego użytku. 
Ius Matrimoniale 7 (13) 2002

\section{Wyrok Sądu Metropolitalnego w Katowicach (c. Sobański) z 10.05.2001 r. z tytułu 1) błędu co do przymiotu osoby, 2) podstępnego wprowadzenia w błąd, 3) niezdolności do podjęcia istotnych obowiązków malzzeńskich (anoreksja).}

\section{Przebieg sprawy:}

HP oraz AO, zawarli małżeństwo 15.9.1979 w kościele parafialnym w K. Ważność tego małżenstwa została zaskarżona przez HP pismem, jakie wpłynęło 12.11.1998 do Sądu Metropolitalnego w Katowicach. Po zasięgnięciu wyjaśnień pozwanej przyjęto sprawę do procesu 18.12.1998. Przedmiot sprawy ustalono 10.2.1999 w formie pytania: „Czy zachodzi nieważność małżeństwa stron z tytulu niezdolności do podjęcia istotnych obowiązków małzeńskich po stronie pozwanej oraz/lub podstępnego wprowadzenia w błąd powoda przez pozwaną oraz/lub błędu powoda co do przymiotu osoby pozwanej"? Odpowiadając na powyższe pytania Sąd orzekł jak następuje:

\section{Stan prawny:}

Zgodnie $\mathrm{z}$ żądaniem skargi rozpatruje się sprawę $\mathrm{z}$ trzech tytułów prawnych, określonych k.1095 n.3, 1097 \&2 i 1098.

1. Kan. $1097 \$ 2$ brzmi: „Błąd co do przymiotu osoby, chociażby był przyczyną zawarcia malżeństwa, nie powoduje nieważności małżeństwa, chyba że przymiot ten był bezpośrednio i zasadniczo zamierzony". Zgodnie $z$ powyższą normą, malżeństwo jest nieważne wtedy, gdy wola małżeńska jest skierowana w pierwszym rzędzie na jakiś przymiot osoby. Przymiot, który jest cechą akcydentalną, staje się przez to intencjonalnym przedmiotem zgody małżeńskiej: w woli nupturienta na pierwszy plan wysuwa się przymiot, osoba schodzi na drugi plan, wybiera się partnera ze względu na przymiot, a nie ze względu na ,jego samego". Istotny jest aspekt subiektywny, tzn. to, czy przymiot ten był wprost i zasadniczo zamierzony i to faktycznie, a nie tylko w sposób domniemany. Nie 
chodzi więc o to, czy ktoś zawierałby małżeństwo „gdyby wiedział”, nie chodzi też o wagę przymiotu - malżeństwo jest nieważne wtedy, gdy dla nupturienta ma znaczenie nie osoba, lecz przymiot.

2. Kan. 1098 brzmi: „Kto zawiera małżeństwo, zwiedziony podstępem, dokonanym dla uzyskania zgody małżeńskiej, a dotyczącym jakiegoś przymiotu drugiej strony, który ze swej natury może poważnie zakłócić wspólnotę życia małżeńskiego, zawiera je nieważnie". Inaczej niż w kan.1097 \$2 chodzi o przymiot ważny, taki, który ,jako taki” może poważnie zakłócić wspólnotę życia małżeńskiego. Należy do takich przymiotów bezpłodność. Małżeństwo jest nieważne wtedy, gdy błąd co do takiego przymiotu został wywołany (1) podstępnym działaniem i to (2) w celu uzyskania zgody małżeńskiej. Owo podstępne działanie to albo kłamstwo albo przemilczenie. Zakłada to, że działający wie o przymiocie - w tym przypadku: bezpłodności - co do którego wprowadza w błąd. Działający musi też być przekonany, że bez zastosowania przezeń podstępu osoba wprowadzana w bląd nie zawarłaby małżeństwa. Nie ma prawnego znaczenia to, czy osoba wprowadzana w błąd zawarłaby malżeństwo, gdyby znala faktyczny stan rzeczy.

3. Kan. 1095 n.3 brzmi: „Niezdolni do zawarcia małżeństwa są ci, którzy: (...) z przyczyn natury psychicznej nie są zdolni podjąć istotnych obowiązków malżeńskich". Norma ta opiera się na założeniu, że nikt nie może prawnie zobowiązać się do czegoś, czego nie jest w stanie wykonać. Niezdolność, o której w k.1095 n.3, wynika z przyczyn natury psychicznej. Nie należy ich utożsamiać z chorobą psychiczną, aczkolwiek choroby takie mogą mieścić się wśród tych przyczyn. Niezdolność ta nie przekreśla zdolności do rozeznania ani ogólnych zdolności życiowych danej osoby - dotyczy istotnych obowiązków małżeńskich.

Istotne obowiązki malżeńskie to te, które wynikają $z$ istoty malżeństwa, ,głębokiej wspólnoty życia i miłości”, obejmującej aspekty nie tylko fizyczne, lecz także duchowe. Istota malżeństwa to „wyjście poza siebie", transcendencja na drugiego czlowieka. Przez zawarcie malżeństwa tworzy się nowa jedność, w której małżonkowie nie przestają być sobą, nie rezygnują $z$ tego, kim i czym są, lecz integrują się w jedność obejmującą całokształt ich życia, właśnie we wspólnotę małżenską. Zaistnienie takiej wspólnoty zakłada zdolność do wzajemnego oddania się i przyjęcia, do wyjścia poza swój własny świat.

W rozpatrywanej sprawie niezdolność pozwanej do podjęcia i wypelnienia istotnych obowiązków małżeńskich jest - wedle skargi - skutkiem jadłowstrętu psychicznego (anorexia nervosa). W literaturze me- 
dycznej znajdujemy następujący opis tej choroby: „Ten uwarunkowany psychogennie zespół objawów jest typowy dla fazy pokwitania. Szczyt zachorowań przypada na wiek 13 lat, spotyka się jednak przypadki znacznie młodszych (najmłodsza opisana pacjentka miała lat 8) lub starszych chorych (nawet z początkiem w trzeciej dekadzie życia). Zdecydowanie przeważają kobiety (relacja ta wynosić ma 30: 1). Sprawa rozpoczyna się zazwyczaj od stanowczej decyzji pacjentek dotyczącej intensywnego odchudzania się. Autorzy francuscy, definiując zespół za pomocą trzech kardynalnych objawów (brak łaknienia, wychudzenie, ustanie miesiączki), mówią o "chorobie trzech A" (anoréxie, amaigrissement, amenorrhée). (...) Jeżeli nawet w okresie przedchorobowym nie wszystkie dziewczęta okazują wyraźną nadwagę, to $z$ reguly w jakiś sposób martwią się swym wyglądem; uważają np., że mają zbyt duży biust, grube uda, „pyzatą" twarz itp. Niekiedy rzeczywiście bywają wyśmiewane przez rówieśników, rodzina zaś bezceremonialnie zwraca uwagę na ich ,zbyt dobry wygląd”, sugerując, że należy mniej jeść, odchudzić się itp. Stopniowo rozwija się patologiczna (w rozmaitym stopniu wyrażana na zewnątrz) postawa panicznego lęku przed otyłością („weight phobia”, „fear of fatness”, wg określeń autorów anglosaskich), przekraczająca zresztą niekiedy rozmiary fobii czy idei nadwartościowej, a sprawiająca wrażenie wręcz reakcji paranoicznej. Towarzyszy temu niezłomne, monoideistyczne dążenie do osiągnięcia maksymalnej szczuplości i utrzymania jej za wszelką cenę. Pacjentki w sposób drastyczny zaczynają ograniczać przyjmowane posiłki i od tej chwili masa ich ciała zaczyna zmniejszać się szybko. Chociaż pierwotny cel, by stać się smuklejszą, dawno został już osiągnięty lub znacznie przekroczony, dziewczęta głodzą się nadal. Wreszcie osiągnięta zostaje granica między wstrzymywaniem się od jedzenia wbrew istniejącemu laknieniu, a jego stopniową, rzeczywistą utratą: pojawia się prawdziwy jadłowstręt. Pacjentki nie chcą przyjąć do wiadomości tego, że pogłębiające się wychudzenie przyczynia się do ich zeszpecenia, do wręcz odrażającego wyglądu „dzieci oświęcimskich”. (...) Wiele chorych ujawnia szczególny „talent do wymiotowania”, zwłaszcza w przypadku zmuszania ich do jedzenia. (...) Unikają wspólnych posiłków, chętnie przygotowują sobie same jedzenie. Pomimo narastającego wyniszczenia długo mogą zachować dobrą aktywność i sprawność psychiczną; są nieraz ruchliwe, wiecznie czymś zajęte, bardzo czynne, a nieraz masochistycznie wręcz gotowe do ofiar. Chętnie gotują i przygotowują wyszukane positki dla całej rodziny, same nie tykając ich nawet. Pilnie uczą się w szkole. 
Dopiero przy bardzo znacznym stopniu wyniszczenia pojawia się bierność i osłabienie, wynikające $z$ upośledzenia funkcji psychoruchowych. (...) Katastrofalnemu niekiedy wychudzeniu, zanikowi tkanki tłuszczowej i mięśni może towarzyszyć obfite wypadanie włosów, obniżenie się temperatury ciała (...) Skóra traci elastyczność, jest wysuszona, łuszczy się, a na szyi i tułowiu pojawia się meszek (lanugo). Dość wcześnie, z reguły jakby nawet zbyt wcześnie, by to interpretować jako wtórny objaw jadłowstrętu, zanika miesiączka" (T.Bilikiewicz, Psychiatria kliniczna, części VII-IX, wyd. 7, Warszawa 1989, 332-333). „W przypadku wczesnego początku zaburzeń (przed okresem pokwitania) dochodzi do zahamowania wzrostu i rozwoju cech plciowych" (J.Aleksandrowicz, Zaburzenia nerwicowe, Warszawa 1998, 110). O osobowości chorych czytamy: „W osobowości przedchorobowej uderzają pewne wlaściwości psychopatologiczne, rozmaicie wyrażone u poszczególnych pacjentek. Cechą wspólną i pierwszoplanową u większości z nich są przesadnie wygórowane ambicje. Dotyczą one szczególnie spraw szkolnych: dziewczęta te starają się osiągać doskonałe wyniki w nauce, dużą rolę w ich życiu odgrywa rywalizacja o pierwsze miejsce w klasie. Niektórym $z$ nich umożliwia to nieprzeciętna inteligencja, mniej zdolne nadrabiają to starannością i pracowitością. Przeważnie są to dzieci nie przysparzające trudności wychowawczych, godne zaufania, posłuszne, bardzo wytrwałe w dążeniu do wytyczonego celu. Oprócz osobowości dynamicznych i syntonicznych zdarzają się dziewczynki nieśmiałe, ciche, wycofujące się, „z kompleksami”, mające trudności w nawiązaniu bliższych kontaktów koleżeńskich i przyjacielskich (których są skądinąd spragnione), przesadnie wrażliwe, o chwiejnym nastroju. U niektórych pacjentek dominują rysy anankastyczne, pedantyzm ze skłonnością do perfekcjonizmu i ascetyzmu. $U$ innych - zaznaczają się przede wszystkim $w$ rozmaity sposób cechy histeroidne, $z$ egocentryzmem, infantylizmem; pewną bezwzględnością w przeprowadzaniu swych zamierzeń; właściwości te ukryte są jednak pod maską uległości í posłuszeństwa. Zaakcentowane w osobowości przedchorobowej cechy ulegają intensyfikacji w już rozwiniętym jadłowstręcie" (T.Bilikiewicz, tamże 333). Cierpiący na tę chorobę odznaczają się ambicją z cechami autodestrukcji. Stosunek do własnego ciała jest narcystyczny i ambiwalentny, koncentruje się na nim a zarazem lękliwie dystansuje się. Nie akceptuje roli - także w sferze plciowej - dorosłej kobiety (W.Schulte, R.Tölle, Psychiatrie, wyd. 5, Berlin - Heidelberg - New York 1979, 80). W literaturze zwraca się uwagę na trudności diagnostyczne - nie zawsze latwo od- 
różnić anoreksję od „schizofrenii z zespolem somatycznym analogicznym do anoreksji psychicznej" (Bilikiewicz, tamże, 334).

Etiopatogeneza anoreksji jest wieloczynnikowa, wchodzą tu w grę „czynniki usposabiające bądź wyzwalające”. Wymienia się wśród nich predyspozycje osobowości, przy czym czynniki osobowościowe i reaktywne pozostają ze sobą w stosunku odwrotnie proporcjonalnym (Bilikiewicz, tamże). Za najbardziej prawdopodobną hipotezę przyjmuje się, że anoreksja jest skutkiem „wykolejonego rozwoju dojrzewania osoby wśród niekorzystnych warunków dzieciństwa" (M.Bleuler, Lehrbuch der Psychiatrie, wyd. 14, Berlin-Heidelberg-New York 1979, 531.

Referowany wyżej stan wiedzy medycznej pozwala dostrzegać anoreksję wśród przyczyn natury psychicznej, o których w kan. 1095 n.3 (Entscheidungen Kirchlicher Gerichte. Leitsätze, Bonn 1999, 5).

\section{Stan faktyczny:}

1. Powód zeznaje, że był zakochany i nie dawał posłuchu ostrzeżeniom, m.in. własnej siostry. Pozwana przyjęła jego oświadczyny natychmiast, nie zastanawiał się nad przyszłością. Przygotowania do ślubu wzięli na siebie rodzice stron i on sam, pozwana zachowywała się przy tym jak księżniczka. W dniu ślubu obydwie strony były szczęśliwe. Pozwana nie brała udziału w urządzaniu mieszkania, niczego nie robiła w domu, strawę przynosiła $\mathrm{z}$ domu, jadała tylko raz na dzień, wieczorem, a $i$ to wymiotowała. Były trudności w pożyciu płciowym, gdyż - pisze to powód w skardze - pozwana odczuwała przy tym duże boleści, jej organy płciowe były ,jak u dziecka”. Powód dowiedział się, że pozwana nie może mieć dzieci. Z upływem czasu pozwana stawała się coraz bardziej agresywna, zagrażala nawet jego życiu. W skardze powoda znajdujemy ponadto informacje, że w r.1980 pozwana załamała się nerwowo, że w rodzinie pozwanej zdarzyły się przypadki chorób psychicznych (samobójstwa siostry ojca), że pozwana nie była zdolna wykonać najprostszych czynności domowych, i że jeszcze w trakcie małżeństwa kąpała ją jej matka.

Uważa przeto powód, że pozwana nie była zdolna do podjęcia istotnych obowiązków małżeńskich oraz że został przez nią oszukany, a w ogóle nie byłby zawierał tego małzeństwa, gdyby wiedział, że jest ono skazane na bezdzietność.

2. Pozwana zeznaje: „W naszym malżenstwie narastaly klótnie $i$ awantury, wtacznie nawet $z$ rękoczynami, dopiero w tych ostatnich 2-3 latach 
naszego matżeństwa - często chodzito o pieniqdze, powód dobrze zarabiat i ja bytam na jego utrzymaniu, często mi to wyrzucat. On praktycznie, choć miat siostre, byt traktowany przez rodziców jak jedynak, byl oczkiem w glowie swych rodziców $i$ uważat, że mu się wszystko należy. Ja bytam mu potrzebna tylko po to, by coś ugotować i pójść z nim do tózka - poza tym powód prowadzil sobie takie kawalerskie życie, nic ze mna nie uzgadniając i robiac wszystko po swojemu, np. potrafit sobie na tydzien na ryby pojechac, nic mi nawet o tym nie mówiac. Poza tym powód i jego rodzice bardzo chcieli zawsze wyjechać na state do RFN - tu byta jeszcze komuna $i$ tam widzieli ten dobrobyt. Ja z góry powiedziałam powodowi, że tu się urodzitam i tu chce pozostać, nigdzie wyjezdżać nie chcę. Uważam, że $w$ matżeństwie $z$ powodem funkcjonowatam dobrze - powód byt oprany, miat zawsze ugotowane positki, byto posprzatane, gdy nie dawałam rady, bo reke już wtedy miatam uszkodzona, to pomagata mi moja mama. Powód byt dwa lata mtodszy ode mnie - może bytam niekiedy zbyt mato tolerancyjna i być może, że nie w petni satysfakcjonowatam powoda seksualnie, byliśmy jednak inaczej zbudowani, ja bytam bardzo szczupła, powód byt dość pokaźnym mężczyzną. Bytam jednak zawsze do jego dyspozycji dzien i noc, bo także w ciagu dnia powód mial zachcianki, aby wspólzyć. Powód byt pierwszym i ostatnim moim chtopakiem - tylko z nim wspótżytam cieleśnie w ciagu mojego życia. Pierwszy raz doszto do stosunku cielesnego między nami na miesiac przed ślubem - bytam wtedy dziewica. Powód stwierdzit, iż nie chce kota $w$ worku kupować $i$ stad doprowadzit do wspólżycia między nami. Już przed ślubem mialam zaburzenia $w$ miesiączkowaniu - nie żebym w ogóle nie miala miesiaczki, tylko byta ona nieregularna. Już wtedy leczytam się u doktora S. - to byto leczenie prywatne i nie mam $z$ tego leczenia żadnej dokumentacji. Powód wiedziat, iż się lecze. Nigdy mi przed ślubem lekarz nie powiedzial, że nie będę mogta mieć dzieci-absolutnie zaprzeczam, jakobym miała wprowadzać w bład powoda, wiedzac już przed ślubem, że jestem nieptodna. Chcieliśmy mieć dzieci, planowałam, że będe miała trójke dzieci - nawet byt moment po ślubie, że miesiaczka się zatrzymała i myślałam, że jestem $w$ ciazzy, ale okazato się, że to tez byto tylko jakieś zaburzenie cyklu. Juz po ślubie zaczęlam się też leczyć u endokrynologa w klinice $w$ Z.". Owa choroba to anorexia nervosis, leczenie hormonalne pozwana kontynuuje do dzis, ma dozywotnia I grupe inwalidzkq "na nogi i kręgoslup”. Jak zeznaje, wyszla za mąż $z$ milości, sadzac, że będa dobrym malżenstwem. W dwa tygodnie przed ślubem wynikta "dość wielka któtnia", rodzice powoda przyjechali $z$ informacja, że trzeba będzie odwotać ślub, ale w kilka dni przed ślubem przyje- 
chat powód, przeprosit $i$ byt ślub. Przestała go kochać już w pierwszym miesiacu po ślubie, bo dawat jej odczuć swa przewage finansowa, przede wszystkim zaś „okazat się typowym samcem”. Nie dat jej nawet pieniędzy na bilet miesięczny, kazat jej chodzić pieszo, bo „ma zdrowe nogi”. Po czterech latach odmówil pieniędzy na leczenie, na adopcję nie zgadzal się.

W piśmie z 25.11.1998 twierdzi pozwana, że na anoreksję zachorowała wskutek zlego traktowania jej przez powoda, a wspólzycie seksualne byłoby normalne, gdyby nie „patologiczne skrzywienie seksualne” powoda, który „wymyślał rzeczy”, od których „włos się jeżyl”. Kąpała się wprawdzie u rodziców, ale to ze strachu przed powodem, który przy myciu pleców zmuszal ją „do prawdziwych orgii”.

3. Pozwana przedłożyła kopie protokołów zeznań z rozprawy rozwodowej. Dnia 29.12.1990 powód podal, ze przyczyną konfliktów małżeńskich był brak potomstwa, a o bezpłodności żony dowiedział się dopiero po ślubie. Dnia 7.2.1991 stwierdzil, że już w 15 dni po ślubie żona oświadczyła mu, iż go nie kocha. Zarzucił wtedy żonie niechęć do leczenia się, brak troski o dom oraz to, że w dwa lub trzy lata po ślubie zaczęła odżywiać się „,w sposób nieprawidłowy”. Dopiero po wyjeździe do Niemiec dowiedzial się, że żona jest inwalidką I grupy. Zaprzeczył, by chudnięcie żony wiązało się z rozpadem malżeństwa. Rozwód orzeczono ,z winy powoda i niezawinionych przyczyn pozwanej”.

4. Siostra powoda GS poznała pozwaną wcześniej niż on, gdyż jest, ona kuzynką męża świadka. Zeznaje: „Wedlug mnie malżeństwo stron rozpadto sie z powodu niedopasowania stron do siebie - w wielu dziedzinach: charakteru, budowy ciata, zycia seksualnego. Pozwana byla bardzo knucha osobq, ważla tylko $40 \mathrm{~kg}$, byta bardzo szczupla - brat skarżyl sie, ze o kazdy stosunek cielesny musi sie prosic, a nawet placić jej za to - to byto dośc glośne $w$ catej naszej rodzinie. $Z$ drugiej strony pozwana skarżyla się, że ja to boli i stad unika czestego wspólzycia cielesnego z bratem. Pozwana byla jedynaczka, rozpieszczona przez matke, także po slubie wiele czasu wysiadywała u niej. Ja już przed ślubem widziałam, że strony nie pasuja do siebie - ostrzegatam brata, że to nie jest dziewczyna dla niego, ale on byt zakochany, to byla jego pierwsza dziewczyna i nie chciat sobie nic dać powiedzieć. Uważam, że pozwana - mimo, że byta kuzynḱ męża - nie nadawata sie do budowania prawdziwego matżenstwa, do spetniania swych obowiazków żony i matki. Brat byt tak zakochany, iż wiele rzeczy nie dostrzegat, ani nie chciat dać sobie powiedzieć - uważam, że byt $w$ blędzie co do pozwanej, która bardzo chciata już wyjść za mqż, to się stato wręcz jej obsesja. Na pewno nie mówita wszystkiego bratu przed ślubem -ja wie- 
dziatam więcej, ale brat nie chciat mnie stuchać. Bytam od brata starsza, więc gdy chodzitam już przed ślubem z moim mężem, wtedy poznatam pozwanq. Już wtedy byta buliczkq, a potem przerodzito sie to $w$ anorexie oczywiscie teraz po dwudziestu latach potrafię to nazwać - wtedy widziatam tylko, że pozwana ma bzika na punkcie swojego odchudzania sie i utrzymywania wygladu dziewczynki. Byza zawsze bardzo krucha. Widziatam też, że jak tylko zacznie chodzić z jakimś chtopakiem, to ten po kilku miesiacach ja rzuca - nie wiem do końca, co bylo tego przyczyna, ale widziatam, że żadnego partnera nie może przy sobie utrzymać dlużej. Brat byt młodszy od pozwanej - od poczatku odradzatam mu te znajomość $z$ niq, ale brat się zakochat i nie szto juz do niego przemówić. Strony poznaty się w styczniu 1978 roku, na naszym ślubie - we wrześniu 1979 brali ślub. Już $w$ tym czasie przedślubnym byly też między stronami nieporozumienia $i$ zerwania, ale nie wiem, $z$ jakich konkretnie powodów. Pozwana byta wybuchowa - juz wtedy chyba miata chory system nerwowy. Ze swym ojcem często „darła koty”, ale z mamq miała wspólny język i szczególnie $z$ niq dużo przebywata. Ta mama wszystko za nia robita - myla jej wtosy, prasowała, gotowata. Także po ślubie pozwana wiele czasu spędzała nadal u swej mamy. Już przed ślubem pozwana zwierzata mi się, że ma zaburzenia w miesiączowaniu - to byty takie rozmowy między kobietami i o tych sprawach bratu nie wspominatam - potegowato to jednak we mnie przekonanie, że brat nie powinien się z niq żenic. Tym bardziej, że pozwana nic $w$ tej dziedzinie nie robita, nie chodzita $z$ tym do zadnego lekarza. Brat przed ślubem na pewno nie wiedziat o tych zaburzeniach - potem po ślubie wiele razy prosit pozwana, aby poszła do lekarza, ale ona nie chciata. Być może obawiala sie, że gdyby lekarz przepisat jej jakieś hormony, to wtedy zaczęlaby tyć, a tego bardzo sie bata, no i tak zamykata sie ta kwadratura kola. Jedno jest pewne, ze pozwana przez ten brak leczenia i uchwycenia zawczasu tych zaburzen doprowadzila do poważnej destrukcji swego organizmu”. Po ślubie strony wedlug swiadka „rozmijaty sie w czasie", bo "powódka prowadzita takie nocne życie, rodzice przyprowadzali ja do domu o $2.00 \mathrm{w}$ nocy, potem spata do $10.00 \mathrm{czy} 11.00$, tak więc oni się nawet niewiele widzieli ze soba, sadzę, że okazji do wspólżycia cielesnego nie mieli za dużo, ale myśle, że pozwana robita to celowo".

Ojciec powoda wie $z$ fotografii, że pozwana jako dziewczyna „byla nawet gruba", potem zaczęła się odchudzać, a gdy wychodzila za mąż była tak chuda, że ,żaden czlowiek nie może być chudszy”. Powód chciał, aby się leczyła, ale ona nie za bardzo chciała. Podczas przyjęć nie siadała przy stole, siadywała w kuchni, jadla ,jak ptak", piła lamp- 
kę wina i dużo paliła. Świadek nie wie, czy pozwana przed ślubem zdawała sobie sprawę ze swej bezpłodności".

Wedle matki powoda pozwana pochodziła z rodziny, „która jest w porządku". Strony zawarły małżeństwo z miłości, wesele było sympatyczne, ale wspólżycie małżeńskie stron nie było normalne. Pozwana trwonila pieniądze, nie wykonywała żadnych robót w domu, nawet głowę myła jej matka. Świadek dowiedziała się, że odchudzając się pozwana przez cztery tygodnie piła tylko wodę, przez co stała się po prostu kaleką. Nie była w stanie jeść dużo, gdy zjadła więcej, od razu wymiotowała. Nie miala jednak złego charakteru. Już po przesłuchaniu świadek przesłała oświadczenie o napadach złości pozwanej.

5. W aktach sprawy znajduje się następująca dokumentacja medyczna:

1) Opinia AZ, biegłego lekarza, sporządzona 27.9.1989 na zlecenie Sądu Rejonowego w K. (z sygnatury wynika, że opinii tej zasięgano w związku ze sprawę rozwodowa). Biegły orzeka: „Badana cierpi na wielognuczolowa niedomoge gnuczolów dokrewnych z pierwotna niedomoga przysadkowa. Opinia poradni endokrynologicznej podpisana przez profesora Z. ma istotne znaczenie w ocenie stanu zdrowia pozwanej. Należy przyjać, że opinia ta byla poparta badaniami poziomu hormonów, których oznaczenie nie jest powszechnie dostępne, poza wybranymi ośrodkami. Badanie przedmiotowe pozwanej wykazało znacznego stopnia niedobór wagi. Nie wynika on jednak ze schorzenia przewodu pokarmowego, lecz jest zwiazany $z$ niedomoga przysadkowo-nadnerczowq. Mate ciśnienie krwi, mata sylwetka serca, płaska krzywa cukrowa przemawiajq za niedoczynnościq kory nadnercza. Niedorozwój narzadu rodnego (USG) z brakiem miesiaczkowania przemawiaja $w$ danym przypadku za niedoborem gonadotropin przysadkowych. W tym zespole zaburzen hormonalnych, adynamia, zawroty głowy, omdlenia należ do obrazu klinicznego. Badana jest niezdolna do pracy. Ewentualnie mogtaby wykonywać prace chatupnicza, odpowiedniq dobrana (niesprawna prawa dtoń) i nie wymagajaca wysilku fizycznego. Konieczna stata kontrola i leczenie w poradni endokrynologicznej".

2) „Wypis z treści orzeczenia” Obwodowej Komisji do Spraw Inwalidztwa i Zatrudnienia z 26.6.1997 treści następującej: „Upośledzenia funkcji organizmu czyniq badanq niezdolna do zatrudnienia, a ze wzgledu na niemożność samodzielnej egzystencji wymaga opieki drugiej osoby, co uzasadnia zaliczenie nadal do pierwszej grupy inwalidów".

3) Opinia bieglej Sądu Rejonowego IG, w której inwalidztwo I grupy uzasadniono następująco: "Niedobór wagi na granicy wyniszczenia, na tle niewydolności hormonalnej przysadki mózgowej i gonad, toczeń 
skórny z nawracajacymi zmianami wrzodziejącymi skóry rąk $i$ stóp, i bólami stawowymi, zaawansowana osteoporoza kregostupa, brak odporności za zakażenie grzybiczne wymagajace dtugotrwatego leczenia, nasilone bóle kregostupa, czynia badana calkowicie niezdolna do pracy".

Brak natomiast dokumentacji ze wcześniejszego leczenia, o którym zeznaje pozwana - $u$ dra $S$. (pozwana twierdzi, że nie ma $z$ tego leczenia żadnej dokumentacji) oraz u endokrynologa $w Z$. na anorexia nervosa (pozwana zapowiedziała, że ją dostarczy, ale tego nie uczyniła).

6. Sąd zwrócił się o opinię do biegłej psycholog. Biegła sporządziła swą opinię w oparciu o akta sprawy oraz badanie psychologiczne pozwanej. Wyniki testu MMPI biegła tak referuje: „Pozwana rzetelnie odpowiedziata na wszystkie pytania testowe. Wyniki skal kontrolnych wskazuja na brak tendencji do świadomego klamsiwa. Wyniki skal klinicznych nie wskazuja na występowanie u pozwanej zaburzeń osobowości oraz zaburzeń. Ujawniaja jedynie psychologiczne przeżywanie sytuacji, w jakiej sie znajduje. Pozwana jawi się jako osoba majaca poważne problemy ze zdrowiem, co znajduje odzwierciedlenie w przedstawionej dokumentacji medycznej. Przejmuje sie swoim funkcjonowaniem somatycznym, co wplywa na obnizenie nastroju, poczucie niezadowolenia z siebie. Nie postrzega tego jednak jako depresji. Jest nastawiona pesymistycznie do życia. To sprawia, że wycofuje sie z życia spotecznego, ograniczając sie jedynie do grona najblizszych. W relacjach interpersonalnych jest wrażliwa. Myśli jasno i racjonalnie. Stara sie doktadnie realizować swoje zobowiazania. Jest niezadowolona $z$ siebie, kiedy nie może ich wypetniać. Wyniki badań uzyskane przez pozwana bardziej wskazuja na przeżwanie przez niq swojej aktualnej sytuacji życiowej niż jakiekolwiek zaburzenia uniemożliwiajace jej prawidlowe funkcjonowanie psychiczne. Uważam, że pozwana byta $i$ jest osobq w normie psychicznej”. Wedle biegłej pozwana „ze względu na jej stan psychiczny była zdolna do podjęcia i wypełnienia istotnych obowiązków małżeńskich". Biegła postulowała, by odnośnie do wpływu choroby somatycznej na funkcjonowanie pozwanej w malżeństwie wypowiedział się odpowiedni specjalista.

7. Biegła psychiatra zwraca uwagę, że w aktach sprawy nie ma dokumentacji medycznej, w której choroba pozwanej byłaby nazwana ,anoreksja nervosa” czyli ,jadlowstręt psychiczny”. Biegła, stwierdzając, że nie może „z całą pewnością stwierdzić, iż dolegliwości, na jakie cierpiala i cierpi pozwana, są spowodowane jadłowstrętem psychicznym", przyznaje jednak, że „wiele faktów z jej życia oraz brak organicznych przyczyn choroby na to wskazuje". Wskazówką diagnostyczną przema- 
wiającą za anoreksją jest te $\dot{z}$ - jak podaje biegła - „duża energia i aktywność przy tak niskiej wadze”. Biegła pisze: „Anoreksja Nervosa pojawia się zwlaszcza u dziewczą bardzo ambitnych, wrażliwych, mato odpornych na porażki, będacych w nadmiernie bliskim zwiazku emocjonalnym z matkq. Pozwana posiada wszystkie te cechy osobowości (opinia bieglego psychologa)".

Wedle bieglej „schorzenie występujace u pozwanej jest schorzeniem psychosomatycznym, znaczy to, iz powodem wystapienia choroby objawiajacej się głównie dolegliwościami somatycznymi jest szeroko rozumiany "uraz psychiczny". Tak więc schorzenie to ma nie tyle skutki psychiczne co przyczyny w psychice. Wobecnym stadium rozwoju choroby dominuja dolegliwości somatyczne, szczegótowo opisywane przez biegtych lekarzy". Poza obniżeniem nastroju nie ma obecnie u pozwanej zaburzeń psychicznych, trudno dziś odtworzyć te cechy osobowości, które doprowadziły do choroby, gdyż działo się to ok. 30 lat temu. Dane z akt sprawy, tzn. znaczny ubytek wagi i zaburzenia miesiączkowania, przemawiają za tym, że wtedy już, tzn. przed 30 laty, nastąpił początek choroby, a jeśli tak - opiniuje biegła - „można powiedzieć, iż pozwana nie była w stanie podjąc istotnych obowiązków małżeńskich w dniu ślubu". Opinię swą uzasadnia biegła następująco: „Schorzenie jakim jest Anoreksja Nervosa nie pozwala na normalne $i$ prawidlowe funkcjonowanie $w$ matżenstwie. Następuje ostabienie popędu seksualnego, a zmiany zanikowe narzqdu rodnego utrudniaja, wręcz uniemożliwiaja odbywanie normalnych stosunków ptciowych, a zaburzenia w wydzielaniu hormonów sa przyczyna bezptodności. Nieumiejętność emocjonalnego odseparowania się od rodziny generacyjnej, zwłaszcza matki, również zaburza prawidtowe funkcjonowanie w matżeństwie. Dolegliwości somatyczne będace konsekwencja wyniszczenia organizmu znacznie utrudniaja normalne funkcjonowanie".

8. Sylwetka pozwanej zarysowana w materiale dowodowym odpowiada opisowi anoreksji, jaki znajdujemy w literaturze.

Biegła psycholog tak napisała o pozwanej na podstawie danych z przeprowadzonego z nią wywiadu: „Pozwana jest jedynaczka. Wychowywata się w mieście. Rozwój przebiegat prawidtowo. Byta wychowywana przez babcię. Nie uczęszczata do przedszkola. Kiedy poszta do szkoty podstawowej, mama zrezygnowata z pracy zawodowej, aby zająć się dzieckiem. Pomagata jej w nauce. Rezygnacja z pracy zawodowej mamy spowodowata pogorszenie się sytuacji materialnej $w$ domu pozwanej. Nie mogli sobie pozwolić już jak dawniej na wszystko, na co mieli ochotę. Musieli sie liczyć z pieniędzmi. Pozwana byla dzieckiem nieśmialym, spokojnym. Nie sprawiata żadnych 
problemów wychowawczych. Byta postuszna ojcu, ponieważ się go zawsze bata. Swoje kontakty z rówiesnikami ograniczata do grona bliskich kolezanek, wśród których czuta sie dobrze i bezpiecznie. Tam byta straszna gaduta. Koledzy wyśmiewali ja, że jest grubaska. Unikata ich towarzystwa. Wśród obcych czuta sie niepewnie. Bedac w szkole podstawowej uczestniczyta w różnych dodatkowych zajeciach. Nalezata do kótka recytatorskiego, Kola Mlodych Twórców. Byta zawsze uczennica celujaca. Pelnita funkcje przewodniczacej samorzadu klasowego. Nigdy nie wagarowata. Po ukończeniu szkoly podstawowej podjela nauke w Ś. (...), w klasie chemicznej. Pobyt $w$ tej szkole bardzo przezywata. Panowat tam rygor $i$ dyscyplina. Uczyla sie po nocach, a pomimo tego spadla w ocenach. Nauka nie szla juz jej tak tatwo jak w szkole podstawowej. Z uczennicy celujacej zaczeła być uczennica dostateczna. Nie mogta się z tym pogodzić. Miata nawet kłopoty z jezykiem polskim, w którym byla bardzo dobra, ponieważ polonistce nie odpowiadat jej styl pisania. Kiedyś otrzymala I nagrode w Konkursie poetyckim (...), a pani z polskiego i tak oceniata ja dostatecznie. Okres szkoty siredniej byt bardzo przykry dla pozwanej. Niemile go wspomina. Poza tym, że miata trudności z naukq miata problemy ze sobq samq. Nie akceptowata swojego wygladu. Bowiem przy wzroście $154 \mathrm{~cm}$. ważla ok. $70 \mathrm{~kg}$. Byta pośmiewiskiem w klasie. W końcu pod koniec III klasy szkoty średniej, zakochata sie $w$ jednym koledze i postanowiła sie odchudzac. Wyjechata na wieś $i$ tam jadta same owoce. W ten sposób zrzucita 10-12 kg. Zmienit się jej wyglad. Byta z siebie zadowolona. Od tego czasu jadta bardzo mato".

W tej relacji mieszczą się typowe, opisywane w literaturze cechy anoreksji: celująca uczennica - trudności w nauce, „grubasek" - spadek wagi, aktywność spoleczna - unikanie towarzystwa, ponadto: pogorszenie się warunków materialnych, zaburzenia menstruacyjne. Powiedziała też pozwana biegłej, że „dzieci nie są potrzebne do szczęścia" - jak wspomniano wyżej, w literaturze podkreśla się, że kobiety cierpiące na anoreksję czują się wolne od roli partnerki i matki. Wprawdzie biegła-psychiatra zauważa, ze brak w aktach dowodu na diagnozę anoreksji i dlatego można o takiej chorobie pozwanej mówić jedynie na podstawie faktów na nią wskazujących, ale trzeba zauwaźć, ze pozwana zeznając sama przyznała, że leczyła się na anorexia nervosa (dopiero u biegłej-psycholog ,nie potwierdziła” takiej diagnozy).

Wynika z powyższego, że pozwana zachorowała na anoreksję, gdy była uczennicą szkoly średniej, czyli z początkiem lat siedemdziesiątych. Choroba ta uniemozliwiała jej normalne funkcjonowanie w malzeństwie, pozwana - mimo dobrej woli - nie byla w stanie zaakcepto- 
wać roli żony i matki. Realizacja tego, co składa się na wspólnotę malżeńską, przekraczała możliwości osobowościowe pozwanej.

9. W rozpatrywanej sprawie nie ma żadnych dowodów na to, by powód zawierał małżeństwo znajdując się w blędzie co do bezpośrednio i zasadniczo zamierzonego przymiotu pozwanej. Powód twierdzi wprawdzie, że nie żeniłby się z pozwaną, gdyby wiedział o jej bezpłodności, z tego nie wynika jednak, że chodziło mu nie tyle o osobę pozwanej, ile o matkę (przyszłych) dzieci. Przeciwnie, powód zeznaje, że był zakochany i nie zastanawiał się nad przyszłością. Takie zeznanie przekreśla mowę o blędzie co do przymiotu wprost i bezpośrednio zamierzonego.

10. Nie znajduje też najmniejszych podstaw twierdzenie powoda, jakoby pozwana wprowadziła go w błąd (co do własnej płodności) kierując się obawą, że $w$ przeciwnym razie mógłby zrezygnować $z$ małżeństwa. Nie udowodniono, by pozwana wiedziała już wówczas o tym, że nie będzie w stanie zrodzić dzieci - a skoro tak, to nie mogla powoda wprowadzić $w$ błąd. Pozwana zeznaje zresztą, że jego siostra ostrzegala go przed malżeństwem $z$ pozwaną, ale on nie słuchal przestróg. Nie widać przyczyn, dla których pozwana musiałaby obawiać się rezygnacji powoda $z$ zawarcia malżeństwa, Ponadto: pozwana zeznaje, że strony zerwały ze sobą przed ślubem i powód sam „przyszedł i przeprosil”.

Wobec takiego stanu sprawy Sąd stwierdza: 1) nie udowodniono, by powód zawieral malżeństwo będąc w blędzie co do przymiotu bezpośrednio i zasadniczo zamierzonego; 2) nie udowodniono, by powód zawieral małżeństwo zwiedziony podstępem co do przymiotu pozwanej mogącego poważnie zakłócić wspólnotę życia małżeńskiego; 3) udowodniono, że pozwana nie była $-\mathrm{z}$ racji psychicznych - w stanie podjąć istotne obowiązki małżeńskie. Tym samym Sąd stwierdza, że udowodniono nieważność małżeństwa.

La sentenza del Tribunale Metropolitano di Katowice (c. Sobański) del 10.05.2001 dal titolo: 1) del errore circa la qualità della persona, 2) deceptionis dolosae, 3) dell'incapacità ad assumere gli obblighi essenziali del matrimonio (anoressia)

\section{Sommario}

Si presenta il testo della sentenza del Tribunale Mertopolitano di Katowice c. Sobański ob errorem circa la qualità („non constare”), ob deceptionem dolosam („non onstare”), ob inapacitatem assumendi (,constare”). 